今日の話題

3) S. M. Reppet \& D. R. Weaver : Nature, 418, 935 (2002).

4) Y. Nakamura et al. :J. Allergy Clin. Immunol., 127, 1038 (2011).

5) Y. Nakamura, Y. Tahara, M. Hara, K. Ishimaru, R.
Katoh, K. Okumura, H. Ogawa, S. Shibata \& A. Nakao: submitted.

(中尾篤人, 山梨大学医学部)

\title{
きのこを用いた連結バイオプロセスによるバイオエタノール製造 コスト削減の救世主となり得るか?
}

近年，地球温暖化対策として，カーボンニュートラル であるバイオマスからエ夕ノール生産を行なう動きが世 界的に活発化しており, 食糧亡競合しないリグノセル ロース系バイオマスからのバイオ燃料製造技術の確立が 望まれている。しかし, 現段階では, リグノセルロース 系バイオマスを原料としたバイオ燃料製造コストは非常 に高く, 実用化の妨げになっている. 現在の変換法の主 流, バイオマスの前処理 $\rightarrow$ 酵素糖化 $\rightarrow$ 発酵を段階的に 行なうプロセス（図 1-A）においては，前処理および糖 化酵素の生産（または購入）に関わる費用がエ夕ノール 製造コストの約半分を占めると算出されており ${ }^{(1)}$, バイ オ燃料の実用化に向け，いかに製造コストを安価にでき るかが大きなポイントとなっている。 そこで, 製造コス 卜削減へ向けた「連結バイオプロセス (Consolidated bioprocessing ; CBP)」という方法が Lynd らにより提 案された ${ }^{(2,3)}$. この方法はコスト削減効果が大きいこと から，次世代新技術として認知されつつある。
CBP は，糖化酵素生産をプロセスに含むことが大き な特徵であり, 酵素生産・糖化・発酵を 1 バッチで行な う変換法である (図 1-B). しかし, CBP を達成しうる完 全な生物は現存していないといわれており，2 通りの方 向性で $\mathrm{CBP}$ 生物の開発へ向けた研究が行なわれてい る. 1 つは Saccharomyces cerevisiae, Kluyveromyces marxianus, Escherichia coli, Zymomonas mobilis など, エ夕ノール生産能の高い生物に糖化酵素生産能を付与す るアプローチである。しかし，複雑な構造をしたリグノ セルロースを完全分解するための多種多様な糖化酵素を 発現させることは困難である。また, 結晶性セルロース の糖化に最も重要といわれるセロビオヒドロラーゼの異 種発現は大変難しく, CBP に適した改良株は得られて いない(4).

もう 1 つのアプローチは, 糖化酵素生産菌にエ夕ノー ル発酵能を付与するエンジニアリングである，嫌気性細 菌 Clostridium thermocellum は最も研究が行なわれて

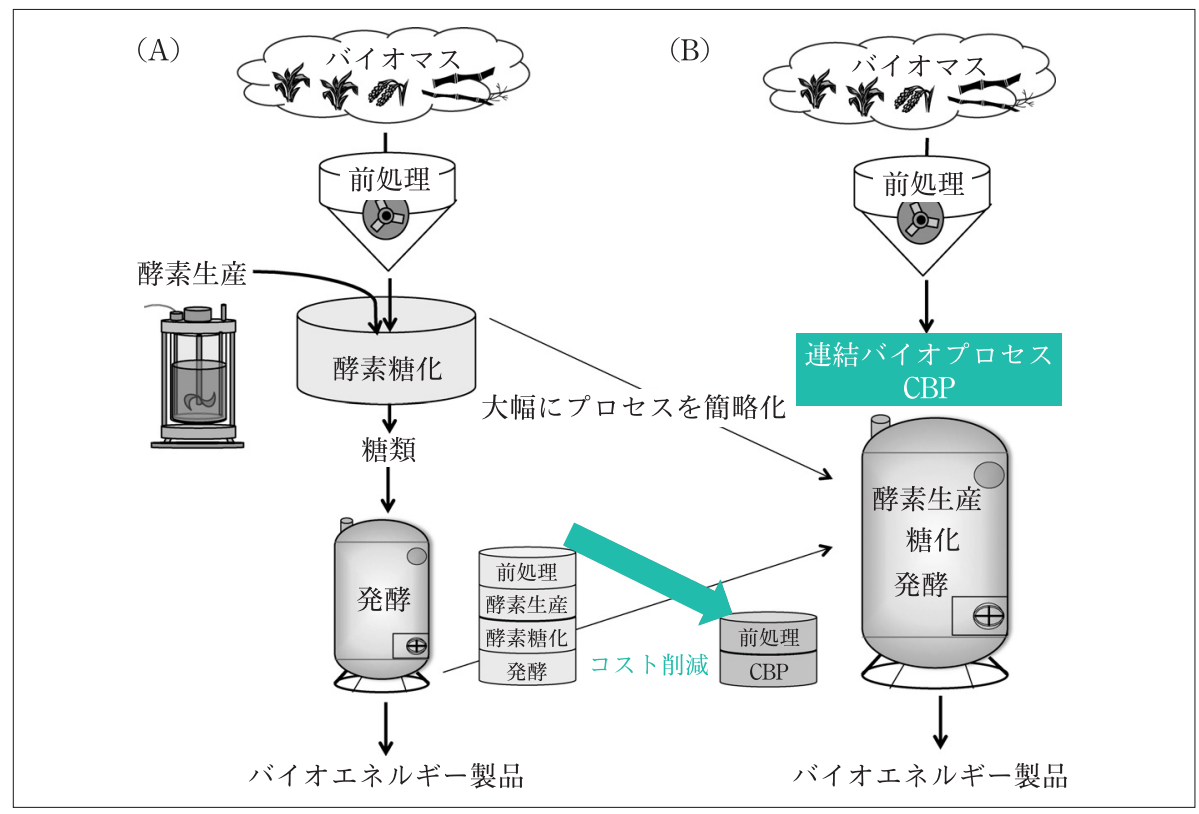

図1"バイオマスからバイオ燃料 生産への流れ

(A) 従来法, (B) 連結バイオプロセ ス 


\section{今日の話題}

いる微生物の一つであり, セルロソームという高いセル ロース分解性を示す巨大なセルロース，ヘミセルロース 分解酵素複合体を生産する ${ }^{(5)}$. また, エ夕ノールを生産 する種も存在することから CBP への利用が提案されて いる. しかし, エ夕ノール耐性がきわめて低い点や, 遺 伝子組換えが非常に困難であることなどが，菌株を改良 するうえで大きなハードルとなっている.

その他，糖化酵素を有し，ヘキソースとペントースの 同時発酵が可能な種が存在する糸状菌は，バイオ燃料製 造において有用であると思われるが，研究は非常に少な い.これは糸状菌のエタノール耐性が低い点が原因であ ると考えられている. また, 上記に挙げた生物はリグニ ンの分解能を有していないことから，バイオマスの前処 理から発酵までのすべてを含めた CBP への利用は困難 であることがうかがえる.

筆者らは, 新たな $\mathrm{CBP}$ 生物の候補として, エタノール を生産する種が存在し, 地球上で唯一単独でリグノセル ロースの完全分解が可能な木材腐朽菌, “担子菌” に着目 し研究を行なってきた. 複数の食用担子菌に対してスク リーニングを行なった結果, エノキタケ (Flammulina velutipes) FV-1 株が優れたエタノール生産能と高いバイ オマス糖化能を有することを見いだした ${ }^{(6)}$. 本菌は，セ ロビオース濃度 $15 \%(\mathrm{w} / \mathrm{v})$ という高濃度条件下におい ても, 高いエタノール変換率を示す。さらにアンモニア 処理後の稲ワラに対しては, ごく少量の糖化酵素の添加
を要するものの，バイオマス濃度 $30 \%(\mathrm{w} / \mathrm{v})$ という高 濃度条件下で，セルロースに対するエ夕ノールの回収率 $76 \%$ という非常に高い変換率を達成しており, CBP 生 物として有望であると考えられる。ささらに筆者らは，工 ノキタケにおける異種遺伝子発現系を構築し ${ }^{(7,8)}$, まず まずの形質転換効率で形質転換体を得ることに成功し た. 異種発現がきわめて困難であり，酵母では上手く発 現できないセロビオヒドロラーゼをエノキタケで発現さ せることにも成功しており，今後 CBPに適したエノキ タケへと改良を進めることを検討している.

エノキタケは言わずと知れた食用きのこであるが，前 述の理由以外にも $\mathrm{CBP}$ 生物としてバイオ燃料製造に利 用するメリットが存在する。きのこ産業は国内の年間生 産額が約 2,240 億円（林業の総生産量の約 $50 \%$ を占め る）の巨大産業である。近年のきのこ栽培は菌床栽培が 主流であり, 木粉, コーンコブ, バガスなどのバイオマ スを菌床に利用することから，バイオマス利用産業とみ なすことができる。また，これだけのバイオマスを利用 している産業は他には存在せず，きのこ産業は実用化し ているバイオマス利用産業としては最大規模である。き のこ収穫後に不要となった廃菌床はきのこ産業的には廃 棄物であり，有料で処分しているのが実情であるが，き のこを $\mathrm{CBP}$ 生物として利用する観点からみると, 廃菌 床はきのこの菌糸とバイオマスの塊であり, 木材腐朽菌 による「前処理」と「糖化酵素生産」を終えた状態と捉

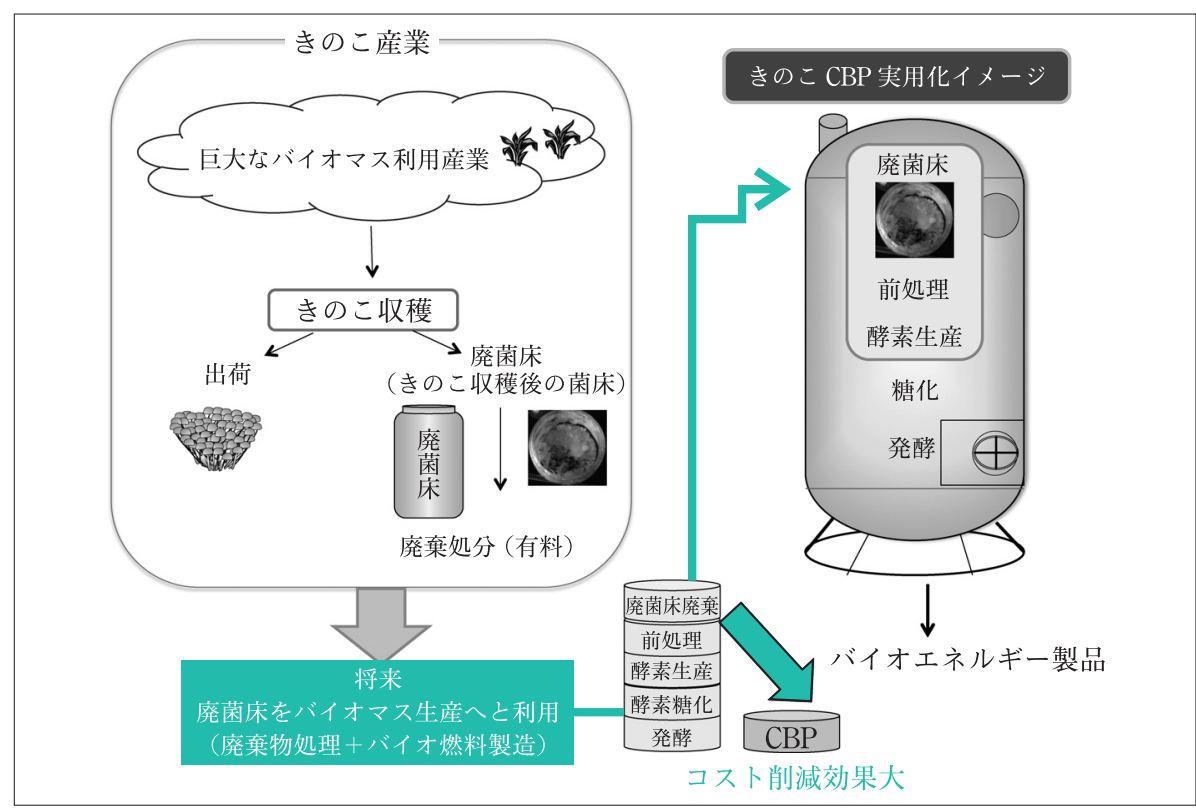

図 2 •きのこ産業ときのこによる CBP 融合のイメージ 
えることができる. したがってバイオ燃料製造を，きの こ産業の廃棄物処理技術（図 2） と位置付けることによ り，バイオ燃料製造における「製造コストが高い」とい う問題も解決できることが期待される.

実用化しているバイオマス利用産業としては最大規模 であるきのこ産業に，バイオ燃料製造を組み込める可能 性が高いことがきのこによる CBP の最大の長所であ り，従来の方法に比べ実用化に近い位置にあると考えら れる。きのこを用いた CBP がバイオ燃料製造における 救世主となり得るかどうかは今後の研究が鍵となるが, 実用技術の開発へ向け, 微力ながら貢献していきたい.

1) Q. Xu, A. Singh \& M. E. Himmel:Curr. Opin. Biotechnol., 20, 364 (2009).
2) L. R. Lynd, P. J. Weimer, W. H. van Zyl \& I. S. Pretorius : Microbiol. Mol. Biol Rev., 66, 506 (2002).

3) L. R. Lynd, W. H. van Zyl, J. E. McBride \& M. Laser : Curr. Opin. Biotechnol., 16, 577 (2005).

4) D. C. la Grange, R. den Haan \& W. H. van Zyl:Appl. Microbiol. Biotechnol., 87, 1195 (2010).

5) E. A. Bayer, E. Setter \& R. Lamed : J. Bacteriol., 163, 552 (1985).

6) R. Mizuno, H. Ichinose, T. Maehara, K. Takabatake \& S. Kaneko: Biosci. Biotechnol. Biochem., 73, 2240 (2009).

7) T. Maehara, M. Yoshida, Y. Ito, S. Tomita, K. Takabatake, H. Ichinose \& S. Kaneko:Biosci. Biotechnol. Biochem., 74, 1126 (2010).

8) T. Maehara, S. Tomita, K. Takabatake \& S. Kaneko: Biosci. Biotechnol. Biochem., 74, 2523 (2010).

（金子 哲, 前原智子, (独)農業・食品産業技術総合 研究機構食品総合研究所)

\section{プロフィル}

池谷 裕二（Yuji Ikegaya） <略歴 > 1998 年東京大学大学院薬学系研究科博士 後期課程修了後, 同大学大学院助手, 講師 を経て, 現在, 同准教授<研究テーマと抱 負 $>$ 脳回路システム<趣味 $>$ クラシック鑑 賞

池田 治生（Haruo Ikeda） <略歴> 1977 年北里大学薬学部製薬学科卒業／ 1982 年同大学大学院博士課程修了 (薬博) $/ 1983$ 年同大学薬学部助手 $/ 1990$ 年同専 任講師 / 1992 年同助教授 / 2002 年同大学 北里生命化学研究所および同大学大学院感 染制御科学府教授, 現在にいたる.この間, 1982 83 年英国ジョンイネス研究所ポス ドク<研究テーマと抱負 $>$ 合成生物学的な
アプローチによる物質生産微生物の改変, 物質生産における分子遺伝学的な解析<趣 味 >下手な楽器演奏, ハードなサイクリン グ

宇治田早紀子（Sakiko Ujita） <略歴> 2010 年東京大学理学部生物学科卒業 / 同 年同大学大学院薬学系研究科薬品作用学教 室修士課程入学, 現在, 在学中 $<$ 研究テー マと抱負＞アストロサイトのカルシウム活 動に関する研究＜趣味＞クラリネットを吹 くこと

大谷美沙都 (Misato Ohtani) <略歴 $>$ 2000 年東京大学理学部生物学科卒業 2005 年同大学大学院理学系研究科博士課
程修了/同年同研究科研究支援員 / 2006 年(独)理化学研究所基礎科学特別研究員 / 2009 年同研究所特別研究員 $/ 2011$ 年同研 究所研究員, 現在にいたる<研究テーマと 抱負 $>$ 植物細胞の屯つ分化・分裂の柔軟性 の仕組みを遺伝子の転写制御〜RNA 代謝 制御〜翻訳制御といった様々な観点から解 き明かしたいく趣味＞美術鑑賞, 読書

大橋 祐子 (Yuko Ohashi) <略歴>1965 年名古屋大学大学院農学研究科修士課程修 了後, 農林水産省農業生物資源研究所を経 て, 現在, 同研究所非常勤職員 $<$ 研究テー マと抱負 $>$ 植物の病傷害応答 $<$ 趣味 $>$ 園芸 など 